\title{
Determining Antecedent of Re-Purchase Intention: The Role of Perceived Value and Consumer's Interest Factor
}

\author{
Yesim $\mathrm{Can}^{1}$, Oya Erdil ${ }^{1}$ \\ ${ }^{1}$ Faculty of Business Administration, Gebze Technical University, Turkey \\ Correspondence: Yesim Can, Faculty of Business Administration, Gebze Technical University, Turkey.
}

Received: January 25, 2018

Accepted: February 20, 2018

Online Published: February 23, 2018

doi:10.5539/ibr.v11n4p17

URL: https://doi.org/10.5539/ibr.v11n4p17

\begin{abstract}
With the widespread use of smartphones, strategic marketing of smartphones has become the focus of related brands. Although creating brand loyalty is an important factor of global strategic marketing and re-purchase intention, little research investigated the antecedent of smartphone's brand loyalty and repurchase intention. The purposes of this study are to investigate what are the antecedent brand loyalty and re-purchase intention in smartphone marketing. In the light of the literature and for this purpose; the effects of perceived value factor (perceived ease of use, perceived irreplaceability), utilitarian factor (system quality), hedonic factor (visual design), and consumer's interest factor (technology consciousness) on brand loyalty and repurchase intention were investigated in an integrated model. The results of the analysis show that smartphone's re-purchase intention is largely determined by brand loyalty, perceived ease of use, perceived irreplaceability, system quality, visual design, and technology consciousness. Moreover, analysis results demonstrate that perceived irreplaceability, system quality, and visual design affect brand loyalty.
\end{abstract}

Keywords: brand loyalty, re-purchase intention, smartphone, technology consciousness, perceived ease of use, perceived irreplaceability, system quality, visual design

\section{Introduction}

With the development of technology, there has been a rapid increase in the use of smartphones all over the world. A smartphone is not just a mobile phone in the lives of consumers; it is also involved in different uses in daily life. Consumers have begun to carry out activities that can be performed on the computer with the smartphone besides the functions of calling and sending messages. For example, it enables the user sending and receiving emails, supplies camera with the data storage capacity, provides internet access (Pitt et al., 2011). In recent years, in addition to these features, with the widespread use of social media, the ability to use social media has increased the importance and demand for smartphones. At the same time, consumers are not only using the smartphone to satisfy their utilitarian needs (making a call, sending a message) but al so to satisfies their hedonic needs (gaining a status). The smartphone must satisfy both types of needs in order to meet consumer expectations.

For a long time, brands have focused on to sustain competitive advantage and increase sales. In order to reach these goals in the long term, brands must be able to understand and respond to the changing demands and needs of the consumer (Webster, 1992). To achieve sustainable competitive advantage and increase sales, brands are implementing various strategies. In this perspective, it has become increasingly important to establish brand loyalty in the consumer (Hallowell, 1996). With previous research, the effect of brand loyalty on the re-purchase intention has been revealed (Dick \& Basu, 1994). Brands that want to maintain their sales and gain competitive advantage have entered into efforts to establish brand loyalty in the consumer. Moreover, brand loyalty in the previous studies of the service sector has been shown as one of the most important factors that generate advantages against competitors (Bharadwaj et al., 1993).

Smartphone use by consumers is growing rapidly. Turkey is one of the countries with the highest usage of smartphones. The high usage of smartphones in Turkey can be attributed to the high young population (Bayraktar et al., 2012). This widespread use offers new opportunities for marketers to meet customer needs (Persaud \& Azhar, 2012). Despite its ever-increasing use and great importance, there are still few studies explaining the antecedent of brand loyalty and re-purchase intention, which affect consumers' smartphone purchasing process (Filieri \& Lin, 2016; Kim et al., 2014). Brand loyalty and re-purchase intention show the idea 
of repeating purchase after the adoption of the technology and consistent use of the customer (Bhattacherjee, 2001). Although the increasing importance of smartphone, there is a scare study in this field in Turkey. Moreover existing studies offers significant insights to understand which factors important in using smartphone, they do not shed light on consumer's interest factor in a holistic model. Furthermore, generally their study center upon a single point of view such as usability (Lee et al., 2015), luxuriousness and attractiveness (Hong et al., 2008), device features (Kim et al., 2016), mobile phone brands (Bayraktar at al., 2012) and technology consciousness has not been adapted as a factor in smartphone marketing. Therefore, technology consciousness with an integrated holistic perspective is a gap in the literature. We aim to fill these gaps and to propose a comprehensive model that enriches the point of view. In this light perspective, the main purpose of this study is to investigate the antecedent of brand loyalty and re-purchase intention in existing smartphone marketing with a holistic model of integrated consumer's interest factor.

We conducted a research to fill the gap in the literature due to the lack of research in the field of smartphone marketing in Turkey. We conducted preliminary research with 10 ungraduated student to identify the factors that are important for smartphone users in Turkey and to develop a new model. We made face-to-face interviews for this purpose and identified the leading factors by using literature studies. Preliminary study and literature research revealed five important factors that are considered to have an effect on brand loyalty and re-purchase intention: perceived ease of use, perceived irreplaceability, system quality, visual design, and technology consciousness.

This research contributes to the literature in three different ways. Firstly, this study presents a different perspective and model by contributing to the small number of studies conducted on consumers' smartphone purchasing processes. Secondly, the results of this study provide useful insight to brands, especially smartphone brands who seek to grow with the global international marketing strategy. Finally, this study has contributed the literature by deriving the concept of technology consciousness from the fashion consciousness where technology consciousness refers to consumer's sensitivity to changing technology.

\section{Theoretical Background}

\subsection{Technology Adoption Theories and Use of Smartphone}

Today, technology is constantly evolving and renewing. Users can be reluctant to accept and use new technological products. Owing to the importance of this problem, user adopted technology has been a long-standing issue and a lot of research have been conducted to understand what factors influence new technologies adoption and how it can be possible to adopt new technologies. Current studies are explaining technology adoption by benefiting from past studies that describe consumer behavior (i.e. Davis's TAM (1989), Ajzen's TPB (1991) or Fishbein and Ajzen's TRA (1975)).

The basic assumption of TAM is that technology adoption lies in perceived values arising from the use of technology (Kim et al., 2014). According to Davis (1989), perceived ease of use and usefulness is an important factor to technology adoption model (TAM). Wang et al. (2015) added perceived enjoyment, perceived irreplaceability, and habit in use of microblogs besides these two factors, which are the two indicators of technology adoption.

According to Theory of Planned Behavior (TPB) behavioral intentions could be predicted by subjective norms, perceived behavioral control, and attitudes toward the behavior. Moreover, behavioral intentions have a direct effect on actual behavior (Ajzen, 1991). Chen et al. (2009) unified TPB and TAM to show adoption of a smartphone with the applications for the smartphone users. Furthermore, they found that perceived usefulness and ease of use effects attitude toward the use of a smartphone.

There is no agreement on the definition of 'smart' phone, but there is a consensus that smartphone is more than a merely mobile or cellular phone. A smartphone is not only provides a call for and sends a message to but also provides an online access, checks emails and other possibilities such as camera and video. (Pitt et al., 2011). Furthermore, smartphone unifies mobile and computing technologies (Filieri \& Lin, 2016) and the most important feature separating it from existing phone is that smartphone provides with installing and running more advanced applications (Kim et al., 2015).

Nowadays, in the smartphone market, there are many brands (Pitt et al., 2011). Smartphones are suddenly reforming competition in mobile phone marketing (Kim et al., 2015). These important developments factors have become the focus of marketing researchers, whereby they have begun to analyze the determinant of smartphone's brand loyalty (Kim et al., 2016; Yeh et al., 2016; Reuver et al., 2015; Shin, 2015) and the antecedents of (re)purchase intention of smartphone (Filieri \& Lin, 2016; Rahim et al., 2016). Moreover, 
diversified research has integrated technology adoption theories with smartphone use to analyze smartphone user's behavior and intention. According to Filieri and Lin (2016), TAM has been considerably adopted to clarify new technologies adoption. Thereby, it is an important factor adoption of smartphone usage.

\subsection{Brand Loyalty}

Brand loyalty can be defined as having a positive attitude toward the brand and continuing to purchase regularly in the long-term. Brand-loyal customers are more price sensitive. Consumers who have a commitment to the brand can pay more for the products (Shin, 2015). This gives the brand a great advantage. For brands, to constitute brand loyalty is an important objective for strategic marketing and it provides brands with sustainable competitive advantage (Dick \& Basu, 1994). Furthermore, cost of keeping existing customers is less than gaining new customers and it can be accomplished by creating brand loyalty (Kim et al., 2016).

A diversity of research has been conducted to investigate the antecedent and the reason for brand loyalty. Two viewpoints have attracted attention: consumer value theory and consumer-brand identification (Yeh, et al., 2016). Firstly, consumer value theory puts forward that consumer's value perception and evaluation of the product is an important antecedent of brand loyalty. This evaluation can be occurring after or during product use (Parasuraman, 1997). If the consumers perceive a high value for the brand, they can be loyal. At the same time, consumer value leads consumers re-purchase behavior (Kim et al., 2016). According to Yang and Petersson (2004), a high value is motivating brand loyalty. On the other hand, a value is based on equity theory. According to equity theory, for the generation of high-value perception, the ratio of the consumer's outcome/input can be high. Namely, consumers should believe that the result is higher than the effort they spend.

Secondly, consumer-brand identification is an important antecedent of brand loyalty. Consumer-brand identification was defined as the perception to integrate brand identity and the consumer's own self-concept. Marketing administrators are seeking to establish on their customers. Therefore, understanding the relationship between brands and consumers is important (Elbedweihy et al., 2016). Prior research has found that the need for self-esteem and the need for self-consistency are the motivators for consumer-brand identification. Consumers conclude that the use of the brand will be higher when it meets their need for self-esteem and if the brand-users image and the consumer's ideal self-image is integrated higher. Another motivator for consumer-brand identification is the need for self-consistency that motives consumers to behave in ways coherent with their actual self because consumers have beliefs about their habits, lifestyles, and identities (Kressmann et al., 2006).

According to Jones and Sasser (1995), customer loyalty is divided into two categories as short-term and long-term loyalty. Short-term loyalty has less insistence to change products with alternatives. On the other hand, long-term loyalty has strong resistance to change products with alternatives. In fact, in long-term loyal customers don't change brand easily which they generally use the brand's product. Therefore, constituting a long-term loyalty is important for brand's strategic marketing planning (Kotler, 1984). Furthermore, brand loyalty motivates consumers to repeat purchase (Tho et al., 2017).

\subsection{Re-Purchase Intention}

Re-purchase intention refers to continued use or purchase after the adoption of a technology (Filieri \& Lin, 2016). Bhattacherjee (2001) studied the Model of Information Systems (IS) Continuance to clarify post-adoption behavior. Although firstly approval of any information systems is a major step to discern IS success, sustaining of an IS is hooked on its continued usage. Therefore, the achievement of an IS depends on consumer's loyalty (Lin \& Ong, 2010).

The IS continuance studies can be divided into two categories: static-type models and process-type models. Static-type models can be based on Ajzen's (1991) theory of planned behavior (TPB) or David's technology acceptance model (TAM) which explains consumer intention and behavior. Process-type models can be based on Oliver's (1980) expectation-confirmation theory (ECT) or Bhattacherjee's (2001) ISC model, which shows feedback process. In fact, the most popular model explaining IS continuance is ISC model. The model explains users' intentions to continue to use with benefiting perceived usefulness, confirmation and satisfaction (Lin \& Ong, 2010). After the first use, consumer's satisfaction or cognitive beliefs might change and it can lead to repeated behaviors or the exact opposite (Filieri \& Lin, 2016).

According to Filieri and Lin (2016), the IS continuance model neglects another motivation of consumers to use technology product, but it is the hedonic aspect of consumption that motivates consumers. In hedonic consumption, emotions, affects, attitudes and satisfaction are directly influenced by the choice of consumption (Moore, 2015). When thinking of smartphones use, visual design (appearance), interpersonal influence or reference groups effects can be the main foundation for purchase intention in the smartphone market. 
Although a wide range of research has been conducted on re-purchase intention, there is still very few researches discussing re-purchase intention of smartphone consumers. Moreover, most of the existing research has neglected technological consciousness that can be influential on re-purchase intention just like the relationship between fashion consciousness and consumption (Lertwannawit \& Mandhachitara, 2012).

\section{Conceptual Framework and Hypotheses}

\subsection{Perceived Value Factor}

The concept of perceived value is based on equity theory. The consumer is aiming for the value of the product, which he/she obtains (Oliver \& DeSarbo, 1988). Perceived value factor is the consumer's general evaluation of the value of a product, which is based on consumer's perceptions (Zeithaml, 1988). Generally looked at by the consumers, a product or brand that has superior attributes than other alternative is selected, because it is expected that product performance had better satisfy consumers' needs (Yeh et al., 2016). Consumers tend to prefer products with high-perceived value. Therefore, companies should focus firstly on perceived value. (Yang \& Petersson, 2004).

\subsubsection{Perceived Ease of Use}

Perceived Ease of Use (PEU) is defined as the use of technology by the individual without too much effort (Hamid et al., 2016). When consumer acceptance or rejection of technologies is largely influenced by PEU, then it influences consumer's behavioral intention either directly or indirectly (Jackson et al., 1997). But it directly affects consumer's attitude towards use (Liu \& Yu, 2017) and intention to use (Abdullah et al., 2016). It can be said that PEU is a key component of technology adoption (Ozturk et al., 2016). Moreover, perceived ease of use is especially important as ways of measuring consumer's satisfaction (Davis, 1989).

Within the context of this study, PEU refers to the extent that users believe that their use of smartphone has not been required too much effort. If the smartphone is easy to use, consumers will be brand loyal and intend to re-purchase. Studies indicate that perceived ease of use is positively associated with re-purchase intention (Chiu $\&$ Wang, 2008). However, the effect on brand loyalty is the one that is missing in the literature. Therefore, we hypothesize that:

H1a: Perceived ease of use will be positively related to brand loyalty.

H1b: Perceived ease of use will be positively related with re-purchase intention.

\subsubsection{Perceived Irreplaceability}

Perceived irreplaceability is based on a perception of the unique usefulness, which causes individual's habitual behavior. The perceived irreplaceability that causes the individual's dependence (Young, 1999) at the same time is important in meeting and satisfying consumer's needs. When consumers believe that 'this product is irreplaceable', they do not want to replace it with another product. Because they feel that the product has a unique value, believe that the product cannot be replaced even with an alike product (Grayson \& Shulman, 2000), and suspend its replacement (Schifferstein \& Zwartkruis-Pelgrim, 2008). From a consumer standpoint, although there is not enough study in the literature, perceived irreplaceability and its effect are gaining importance. Pedeliento et al. (2016) empirically showed that there is a positive relationship between product irreplaceability and brand loyalty. They applied a research on the drivers in the field of industry. Because of the limited amount of research about perceived irreplaceability, by changing the application of research for in smartphone marketing, this research tests for the existence of a positive relationship between perceived irreplaceability and brand loyalty. Moreover, whether the effect of perceived irreplaceability on re-purchase intention exists can be hypothesized as follows:

H2a: Perceived ease of use will be positively related to brand loyalty.

H2b: Perceived ease of use will be positively related with re-purchase intention.

\subsection{Utilitarian Factor}

Utilitarian factor could be explained with a total evaluation of functional benefits. In terms of utilitarian factor, consumers behave rationally in general (Ozturk et al., 2016) and they want to purchase products without losing time (Chung, 2015). Utilitarian factor derives from consumer's experience of a product (Katz, 1960). Moreover, according to utilitarian factor, the consumer tends to re-purchase the products when they are satisfied with as a result of their use. Furthermore, when the brand is seen as a value, the utilitarian factor leads to brand loyalty (Russell-Bennett et al., 2013). 


\subsubsection{System Quality}

System quality was understood as a consumer evaluation of system performance when satisfying the needs (Shin, 2009). When consumers are having trouble with the system (for example; lack of access or continuous attachment in the system) they are unwilling to use a smartphone (Suki, 2012).

In this research, system quality can be defined as a smartphone's physical characteristic, which enriches consumer's perception. System quality is the antecedent of efficient constructs (DeLone \&McLean, 2003). Shin (2015) examined the effect of system quality on hedonicity, the utility of smartphone and customer satisfaction. The empirical findings showed that there is a positive effect of system quality on hedonicity, the utility of smartphone and customer satisfaction.

Diverse research showed the relationship between system quality and customer satisfaction and continuance intention to use (i.e. Lee \& Lin (2005), Jeong \& Jang (2010), Kim et al. (2015) and Lee et al. (2010)). In line with these studies, we propose the following hypotheses:

H3a: System quality will be positively related to brand loyalty.

H3b: System quality will be positively related with re-purchase intention.

\subsection{Hedonic Factor}

Consumers do not always buy a product thinking it will only benefit. Sometimes the consumer's purchasing of the product can be emotional and sensory. Hedonic factor refers to consumer's purchase decisions with emotional and sensory reasons (Moore, 2015) and affects the attitude, preference, and satisfaction of the consumer (Khan et al., 2005).

\subsubsection{Visual Design}

Visual Design is the aesthetic quality of a product (Kim et al, 2016) and it has a great importance for consumer preference. Various research has been conducted to investigate the effect of visual designs for diversity product types such as electronic products, mobile phones, cars etc. (Han et al., 2000; Hong et al., 2008; Yun et al., 2001). It can be concluded that visual design can influence consumers' behaviors.

The consumer is more likely to be influenced by visual characteristics when they are unstable. (Kahn, 2016). According to Milosavljevic et al. (2012) when consumers are hesitant among similar products, they prefer the visually appealing product. Moreover, Kim et al (2016) found that visual design affects customer satisfaction. In line with these studies, we proposed the relationship between visual design and brand loyalty and repurchase intention.

H4a: Visual Design will be positively related to brand loyalty.

H4b: Visual Design will be positively related with re-purchase intention.

\subsection{Consumer's Interest Factor}

In this study, the consumer's interest factor describes the individual awareness that the consumer is interested in. When we look at the fashion studies, it can be defined as 'fashion consumers are the individuals of interest.' (Han et al., 2016). In line with this perspective and by thinking the relationship between consciousness and purchase intention (Lin et al., 2015), it can be said that technology consciousness is a consumer's interest factor.

\subsubsection{Technology Consciousness}

The rapid de velopment of technology has increased the competition between brands selling technology products. Brands are constantly innovating in their products in order to adapt to the dynamic market structure (Ince et al., 2016). Brands have gained a sustainable competitive advantage by innovating their products or adding different features to their products (Guan \& Ma, 2003).

Technology has a constantly changing structure, just like fashion. Consumers receive the latest model of a product to follow the technology (Miller et al., 1993). The ever-changing fashion and innovations in the product evoke the desire to have the best consumer and the latest model. The consumer feels unsatisfied and unhappy when he does not have the best and the latest model (Firat, 1991; Lertwannawit \& Mandhachitara, 2012). Therefore, brands are trying to satisfy the unending newness demand of consumers by making technological innovation in their products (similar to fashion products) (Barnes \& Lea-Greenwood, 2006).

In this study, technology consciousness, which derives from fashion consciousness, is an equivalent to technological involvement. Consumers whose consciousness of technology is high have solely the desire for and adoption of up-to-date styles (Walsh et al., 2001) and affects consumer's lifestyle, purchase decision and 
behavior (Lee et al., 2009). People who are highly technology conscious may pay more attention to the image portrayed by brands that add innovation to their products.

The effect of consciousness on purchase intention is known as previous studies (Lin et al., 2015). Lertwannawit and Mandhachitara (2012) empirically found that there is a positive relationship between fashion consciousness and status consumption. When it comes to technology products, there is a limited research on consciousness. The following hypotheses have been developed concerning the technology consciousness, brand loyalty and re-purchase intention created by looking at the technology market:

H5a: Technology consciousness will be positively related to brand loyalty.

H5b: Technology consciousness will be positively related with re-purchase intention.

\subsection{Brand Loyalty and Re-Purchase Intention}

Brand loyalty is a promise that consumers will repurchase their favorite brands and will not change their loyalty under whatever condition (Oliver, 1980). According to Dick and Basu (1994), brand loyalty is a key factor to constitute repeat purchase. Prior research found that brand loyalty positively influences purchase intention (Mittal et al., 1998; Das, 2014; Hennig-Thurau et al., 2002). Thus, we de velop the final hypothesis of this study as follows:

H6: Brand Loyalty will be positively related to re-purchase intention.

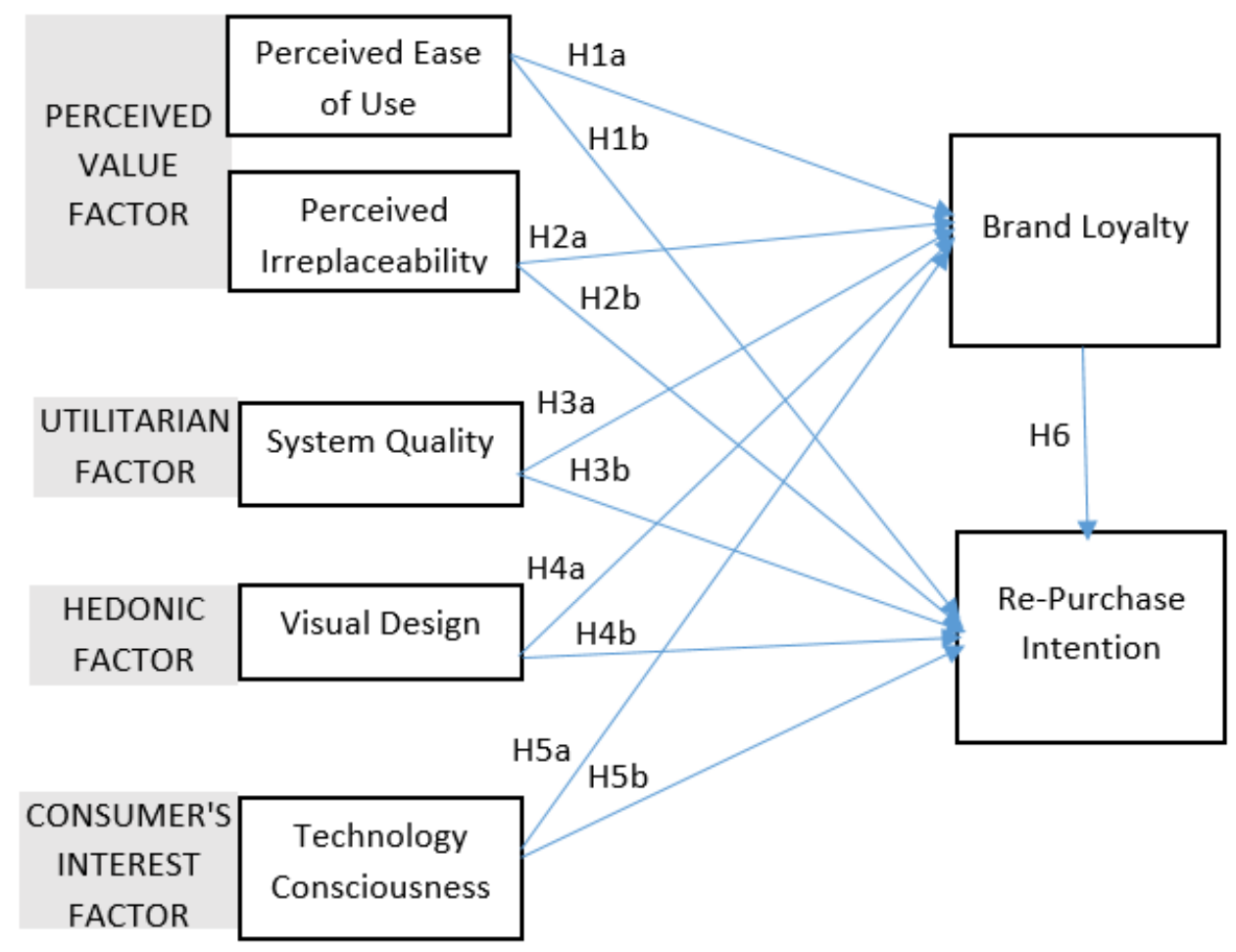

Figure 1. The Conceptual Model of the Study

\section{Research Methodology}

\subsection{Measurement Development}

The purpose of this study is to propound a new theoretical framework to clarify the linkages between brand loyalty and re-purchase intention of smartphone users. For this purpose, we have tried to determine the factors that are considered by smartphone users in Turkey in choosing smartphones by means of observation and face-to-face interviews. Ten ungraduated students has participated in preliminary research. Participants were asked the following questions: What are the important features for you on the smartphone? Why do you buy a smartphone? What attributes will you pay attention if you buy a smartphone again? Then, we compared the factors, which we obtained as a result of an interview with the existing factors given in the literature.

At the end this process; visuality, quality, easy use, uniqueness and technological innovation were found to be the leading factors. We have created hypotheses of working with the leading factors by adapting them with the 
previous studies in the literature and adopted a survey to examine the hypotheses and the research model. All measurement items in the research were modified and adapted from previous research. All items were measured with Likert scales (from 1 . strongly disagree to 5 . strongly agree). Table 1 shows measurement items and related previous literature.

Table 1. Measurement Items

\begin{tabular}{|c|c|c|}
\hline Construct & Measurement Items & Related Studies \\
\hline Perceived Ease of Use & $\begin{array}{l}\text { PEU1 It's easy to use my smartphone } \\
\text { PEU2 My smartphone is useful } \\
\text { PEU3 The use of smartphone is comprehensible and clear } \\
\text { PEU4 My smartphone is elastic to use }\end{array}$ & $\begin{array}{l}\text { Davis (1989), } \\
\text { Wang, et al. (2015) }\end{array}$ \\
\hline Perceived Irreplaceability & $\begin{array}{l}\text { PI1 I cannot find a phone to use instead of my smartphone. } \\
\text { PI2 I do not belie ve the other phone will provide the value that my } \\
\text { smartphone I am using gives me. } \\
\text { PI3 I do not see other smartphone brands equal to the smartphone } \\
\text { brand I use. } \\
\text { PI4 The smartphone brand I use is unique for me in other brands. }\end{array}$ & $\begin{array}{c}\text { Pedeliento, et al. } \\
\text { (2016) }\end{array}$ \\
\hline System Quality & $\begin{array}{l}\text { SQ1 The speed of my smartphone is fast. } \\
\text { SQ2 The brightness of my smartphone's screen and graphics are } \\
\text { perfect. } \\
\text { SQ3 The performance of my smartphone is consistent. }\end{array}$ & Kim et al. (2015) \\
\hline Visual Design & $\begin{array}{l}\text { VD1 My smartphone looks nice. } \\
\text { VD2 My smartphone looks visually pretty. } \\
\text { VD3 The design of my smartphone is very good. }\end{array}$ & $\begin{array}{l}\text { Kim et al.2016 and } \\
\text { Cyr et al., } 2006\end{array}$ \\
\hline Technology Consciousness & $\begin{array}{l}\text { TC1 When the smartphone brand which I use is coming up with an } \\
\text { upper model, it is absolutely interesting. } \\
\text { TC } 2 \text { When the smartphone brand which I use is coming up with a } \\
\text { top model, I would like to change my smartphone to the top model. } \\
\text { TC3 I usually have the latest model of the smartphone brand I used. } \\
\text { TC4 If I see an upper model of the smartphone brand I used in } \\
\text { another person, I would definitely notice it. } \\
\text { TC5 Technologically, the latest model of a product is important to } \\
\text { me. }\end{array}$ & $\begin{array}{l}\text { Lertwannawit } \\
\text { \&Mandhachitara } \\
\text { (2012), Shim } \\
\text { \&Gehrt, (1996) }\end{array}$ \\
\hline B rand Loyalty & $\begin{array}{l}\text { BL1 I think that my smartphone brand is the best for me. } \\
\text { BL2 I say favorable things other people about my smartphone } \\
\text { brand. } \\
\text { BL3 I suggest my smartphone brand when someone asks me my } \\
\text { advice. } \\
\text { BL4 In the future, If I need a smartphone, the brand of smartphone, } \\
\text { which I used first, comes to my mind. }\end{array}$ & $\begin{array}{l}\text { Bayraktar et al., } \\
2012 \text { and Yeh et al. } \\
(2016)\end{array}$ \\
\hline Re-Purchase Intention & $\begin{array}{l}\text { RPI1 I would buy this brand phone again, if I were to buy a } \\
\text { smartphone. } \\
\text { RPI2 If I were shopping to buy a smartphone, the possibility of } \\
\text { buying the same smartphone brand is very high. } \\
\text { RPI3 If I need a smartphone, I would be re-thinking of buying this } \\
\text { brand smartphone. } \\
\text { RPI4 In the future, It is very likely that I will buy this smartphone } \\
\text { brand again. }\end{array}$ & $\begin{array}{l}\text { Fiileri } \\
\text { (2016) }\end{array}$ \\
\hline
\end{tabular}

Perceived value factor comprises of perceived ease of use and perceived irreplaceability, which is considered as an important factor in the use of the technological product (Davis, 1989; Pedeliento, et al., 2016). Perceived ease of use is measured in terms of its use, clear and understandable usage and flexible use (Davis, 1989; Wang, et al., 2015). Perceived irreplaceability is measured in terms of its uniqueness and being equal another smartphone brands (Pedeliento, et al., 2016).

Utilitarian factor consists of system quality and visual design. System quality is measured from the perspectives of smartphone's speed, consistency, screen and graphics (Kim et al., 2015). Visual design measures evaluation of smartphone appearance and looks like (Kim et al., 2016; Cyr et al., 2006).

Consumer's interest factor comprises of technology consciousness. Technology consciousness is adapted from Lertwannawit and Mandhachitara (2012) research. The term of technology consciousness is derived from fashion consciousness. Like fashions products, technological products are evolving and renewing. Brands are trying to create technology awareness by adding new technological features to their products. Technology consciousness is measured by the awareness that occurs in the consumer when the new feature is added to the product or the top model of the product is released. 
Brand loyalty is measured in terms of consumer's obedience and belief that the smartphone that they use is the best. Moreover, it refers to reporting to other people and making suggestions (Bayraktar et al., 2012; Yeh et al., 2016). Re-purchase intention attributes to consumer's thinking of again purchase decisions of smartphone (Fiileri \&Lin, 2016).

\subsection{Sample}

According to a survey conducted by Pew Research Center (2016), the rate of smartphone usage in Turkey between the ages of 18 and 34 is 93 percent. This research shows that the vast majority of young people use smartphones. For this reason, we have chosen the sample as all the students who are educated at the university and who use smartphones. We applied the research to undergraduate, graduate and doctoral students. We collected data from 273 students who were in college and were at +18 years of age.

Table 2 shows the respondents' demographic characteristics. The sample comprises $53.5 \%$ males and $46.5 \%$ females and their ages are ranged from 18 to 52. The majority age of respondents was in the 18-25 range of age. About $44 \%$ of the respondents are in Bachelor, and 39.6\% are in Master and 16.8\% are Doctoral students. When we look at Table 2, we see that the majority of the sample uses IPhone (approximately 44\%). Samsung is ranked second (30\%), followed by LG (10.3\%).

Table 2. Demographics of Respondents $(\mathrm{n}=273)$

\begin{tabular}{|c|c|c|c|c|c|c|c|}
\hline Attribute & Categories & $\#$ & $\%$ & Attribute & Categories & $\#$ & $\%$ \\
\hline Gender & Male & 146 & 53.5 & \multirow{5}{*}{ Income } & $<1.000 \mathrm{TL}$ & 106 & 38.8 \\
\hline & Female & 127 & 46.5 & & $1.001-3.000 \mathrm{TL}$ & 56 & 20.5 \\
\hline \multirow{5}{*}{ Age } & $18-25$ & 132 & 48.4 & & $3.001-5.000 \mathrm{TL}$ & 67 & 24.5 \\
\hline & $26-33$ & 100 & 36.6 & & $5.001-7.000 \mathrm{TL}$ & 21 & 7.7 \\
\hline & $34-41$ & 33 & 12.1 & & $>7.001 \mathrm{TL}$ & 21 & 7.7 \\
\hline & $42-49$ & 7 & 2.6 & \multirow{7}{*}{$\begin{array}{c}\text { Smartphone } \\
\text { Brand }\end{array}$} & Phone & 119 & 43.6 \\
\hline & $>50$ & 1 & 0.4 & & Samsung & 83 & 30.4 \\
\hline Marital & Single & 197 & 72.2 & & LG & 28 & 10.3 \\
\hline Status & Married & 76 & 27.8 & & Sony & 15 & 5.5 \\
\hline \multirow{3}{*}{ Education } & Bachelor & 119 & 43.6 & & Asus & 8 & 2.9 \\
\hline & Master & 108 & 39.6 & & HTC & 7 & 2.6 \\
\hline & Doctor & 46 & 16.8 & & Others & 13 & 4.7 \\
\hline
\end{tabular}

In addition to demographics questions and which smartphone is used, we asked that 'are the last two smartphones which you bought the same brand?' $38.1 \%$ of respondents answered that 'Yes, they are the same brand', on the other hand, $61.5 \%$ of respondents answered that 'No, they aren't the same brand.'

\section{Results}

\subsection{Measurement Model}

The research model and hypotheses were tested with structural equation model using Amos 22 and maximum likelihood procedure included all of the items: perceived ease of use, perceived irreplaceability, system quality, visual design, technology consciousness, brand loyalty and repurchase intention. In order to evaluate the reliability and validity of the construct, firstly we conducted exploratory factor analysis (EFA). Then for each of the constructs in the model, we implemented confirmatory factor analysis (CFA) (Fornell \& Larcker, 1981). After the model was tested, we analyzed the overall model fit and to test the hypotheses we applied path coefficient.

After discarding one item of re-purchase intention (If I were shopping to buy a smartphone, the likelihood I would purchase the same smartphone brand is very high), the complete measurement model showed satisfactory statistical fit. The proportion of the chi-square value and degrees of freedom is lower than five $(\chi 2 / \mathrm{df}=2,35)$. The obtained result model is highly compatible with the dataset: $\left(\chi^{2}(278)=566,602, \mathrm{CFI}=0,94, \mathrm{IFI}=0,94\right.$, $\mathrm{TLI}=0,93$ ). The root means square error of approximation was below the recommended thresholds (RMSEA= $0,06)$. In addition, PNFI is calculated as 0.76 , which is greater than the breakpoint of 0.70 . The test results show that the goodness of fit of the measurement model is acceptable. Table 3 shows the validity and reliability analysis result.

Each measurement scale was evaluated as reliable: The average variance extracted (AVE) and composite reliability (CR) of each of the constructs were over or on the same level the recommended thresholds in order of 0.6 and 0.5 (Fornell \&Larcker, 1981). In addition, Cronbach's alphas ranged from a maximum of 0.95 to minimum of 0.79 , which is greater than the 0.70 thresholds. In addition to the convergent validity of the variables, we checked all of the standardized parameters and they were greater than 0.50 and loaded onto the expected latent construct. 
Table 3. Validity and Reliability Analysis Result

\begin{tabular}{|c|c|c|c|c|c|c|c|c|}
\hline Variables & & 1 & 2 & 3 & 4 & 5 & 6 & 7 \\
\hline Perceived Ease of Use & 1 & $(0.72)$ & & & & & & \\
\hline Perceived İrreplaceability & 2 & 0.06 & $(0.82)$ & & & & & \\
\hline System Quality & 3 & 0.08 & $0.21^{* * *}$ & $(0.84)$ & & & & \\
\hline Visual Design & 4 & 0.01 & $0.15^{* *}$ & $0.59^{* * *}$ & $(0.94)$ & & & \\
\hline Technology Consciousness & 5 & 0.03 & $0.46^{* *}$ & 0.53 & 0.10 & $(0.71)$ & & \\
\hline Brand Loyalty & 6 & 0.10 & $0.52^{* *}$ & $0.39^{* *}$ & $0.39^{\text {** }}$ & $0.39^{* *}$ & $(0.78)$ & \\
\hline Re-Purchase İntention & 7 & $0.23^{* *}$ & $0.31^{\text {** }}$ & $0.32^{* *}$ & $0.33^{* * *}$ & $0.17^{* *}$ & $0.51^{* *}$ & $(0.92)$ \\
\hline Mean & & 3.96 & 2.85 & 3.84 & 4.08 & 2.66 & 3.56 & 4.09 \\
\hline SD & & 0.61 & 1.07 & 0.85 & 0.97 & 0.98 & 0.83 & 1.27 \\
\hline AVE & & 0.51 & 0.67 & 0.70 & 0.88 & 0.50 & 0.61 & 0.85 \\
\hline C.R. & & 0.80 & 0.89 & 0.87 & 0.95 & 0.79 & 0.86 & 0.94 \\
\hline Cronbach's $\alpha$ & & 0.79 & 0.89 & 0.88 & 0.96 & 0.79 & 0.85 & 0.95 \\
\hline
\end{tabular}

Later we contrasted the squared correlations for all of the pairs of latent variables and the AVEs in order to assess the discriminant validity of the constructs. It has been calculated that the square root of the AVEs for each variable is greater than the correlation of the implicit variables between the variable pairs, as proposed by Fornell and Larcker (1981). After completing these tests, it was concluded that the convergence and discriminant validity of the research scales were sufficient.

\subsection{Structural Model}

The proportion between the chi-square value and degrees of freedom was in a receivable field $(\chi 2 / \mathrm{df}=2.66)$ and the structural model showed a good level of fit $(\chi 2(289)=822.308 ; \mathrm{p}<.005, \mathrm{IFI}=0,90, \mathrm{CFI}=0,90, \mathrm{RMSEA}=$ 0,07). Table 4 shows the results for statistical tests of the research hypotheses and the structural model.

Table 4. Hypothesis Analysis Results

\begin{tabular}{llll}
\hline & Path & Path Value & Result \\
\hline H1a & Perceived Ease of Use $\rightarrow$ Brand Loyalty & 0.06 & Not supported \\
H1b & Perceived Ease of Use $\rightarrow$ Re-Purchase Intention & $0.19^{*}$ & Supported \\
H2a & Perceived İreplaceability $\rightarrow$ Brand Loyalty & $0.47^{* *}$ & Supported \\
H2b & Perceived İreplaceability $\rightarrow$ Re-Purchase Intention & $0.27^{* *}$ & Supported \\
H3a & System Quality $\rightarrow$ Brand Loyalty & $0.22^{* *}$ & Supported \\
H3b & System Quality $\rightarrow$ Re-Purchase Intention & $0.28^{* *}$ & Supported \\
H4a & Visual Design $\rightarrow$ Brand Loyalty & $0.29^{* *}$ & Supported \\
H4b & Visual Design $\rightarrow$ Re-Purchase Intention & $0.23^{* *}$ & Supported \\
H5a & Technology Consciousness $\rightarrow$ Brand Loyalty & 0.06 & Not supported \\
H5b & Technology Consciousness $\rightarrow$ Re-Purchase Intention & $0.10^{*}$ & Supported \\
H6 & Brand Loyalty $\rightarrow$ Re-Purchase Intention & $0.67^{* *}$ & Supported \\
\hline$* \mathrm{p}<0,05$ & $* * \mathrm{p}<0,01$ & &
\end{tabular}

Findings revealed that the hypothesized relationship between perceived ease of use and brand loyalty is not supported (H1a rejected) $(\beta=0.06 ; \mathrm{p}>0.05)$, but the perceived ease of use is positively related with re-purchase intention $(\beta=0.19 ; \mathrm{p}<0.05)$. Thus, $\mathrm{H} 1 \mathrm{~b}$ is supported.

Perceived irreplaceability is positively and significantly related with both brand loyalty $(\beta=0.47 ; p<.001)$ and re-purchase intention $(\beta=0.27 ; \mathrm{p}<.001)$. Therefore, $\mathrm{H} 2 \mathrm{a}$ and $\mathrm{H} 2 \mathrm{~b}$ are supported.

The structural path analysis renders support for $\mathrm{H} 3 \mathrm{a}$ and $\mathrm{H} 3 \mathrm{~b}$ : System quality is positively and significantly related to brand loyalty $(\beta=0.22 ; p<0.01)$ and re-purchase intention $(\beta=0.28 ; p<0.01)$. In addition, visual design has a noteworthy effect on brand loyalty $(\beta=0.29 ; p<0.01)$ and re-purchase intention $(\beta=0.23 ; p<0.01)$. Therefore, $\mathrm{H} 4 \mathrm{a}$ and $\mathrm{H} 4 \mathrm{~b}$ are supported.

Finally, the hypothesized relationship between technology consciousness and brand loyalty is not supported (H5a rejected) $(\beta=0.06 ; p>0.05)$, but technology consciousness is positively explained by the proposed antecedent of re-purchase intention $(\beta=0.10 ; \mathrm{p}<0.05)$. Thus, H5b is supported and the last hypothesis about the effect of brand loyalty on re-purchase intention (H6) is supported with a positive and significant degree $(\beta=0.67 ; p$ $<0.01)$.

\section{Discussion}

In this study, the effect of perceived ease of use, perceived irreplaceability, system quality, visual design, technology consciousness on brand loyalty and re-purchase intention were investigated. The results show that the model is effective in clarifying consumer' re-purchase intention antecedents in smartphone marketing. Moreover, 
this study also demonstrates that there is technology consciousness for technological products just like fashion consciousness.

\subsection{Conclusions and Implications}

Despite increased competition and importance for technology firms, few experimental studies have been conducted especially in the smartphone market in Turkey. We used observation and individual face-to-face interview methods to determine the factors that smartphone users in Turkey are attaching as important. At the end of this process, as predecessors of brand loyalty and re-purchase intention we decided to investigate the effect of perceived ease of use, perceived irreplaceability, system quality, visual design, and technology consciousness. Analysis results have shown that the model is effective in explaining brand loyalty and repurchase intention.

This study tested the influence of perceived ease of use on brand loyalty and repurchase intention. Perceived ease of use of smartphone was found to exert influence on re-purchase intention but not on brand loyalty. Our findings have been found to be parallel with previous literature where there exists the effect of perceived ease of use on re-purchase intention (Chiu \& Wang, 2008). According to Ashraf et al. (2016), perceived ease of use has an effect on purchase intention. Hamid et al. (2016) found that perceived ease of use affects the continuance intention of using the e-government services. As a parallel with these studies, in this study perceived ease of use has an effect on re-purchase intention of the smartphone. However, there is no effect on brand loyalty. In this regard, brands, which produce smartphones, should provide easy-to-use phones for consumers to comprise re-purchase intention.

Another finding of this study is that perceived irreplaceability has a significantly important effect on brand loyalty and repurchase intention. Pedeliento et al., (2016) investigated the relationship between perceived irreplaceability and brand loyalty in industrial marketing. They found that there is a positive relationship between them. With this study, when it comes to the smartphone market, our findings are consistent with that of their findings. Moreover, the results revealed that perceived irreplaceability had the most impact on brand loyalty. Brands should improve strategic marketing programs to gain opportunities against their rivals. Providing additional programs, enjoyment content, and usage can maintain the brand to gain perceived irreplaceability. If consumers believe that the product, which they use, is unique, they do not want to replace it with another brand. Eventually, consumers will be brand loyal and continue to use the product.

Consumer buying behavior is affected by both utilitarian factor and hedonic factor (Chung, 2015). In this study, system quality (as an utilitarian factor) and visual design (as a hedonic factor) were investigated. Findings turned out that system quality and visual design are the antecedents of brand loyalty and re-purchase intention in smartphone marketing. When brands design new models, they should not ignore product's appearance and system's architecture. Brands should focus on ensuring the design of the smartphone as beautiful. In this study, system quality refers to system's speed, smartphone's screen, graphics, and performance consistency. When the brands' design phones system, these factors must be taken into account. For smartphone brands, to identify what consumers want and concentrate on satisfying consumer's desire is very important (Kim et al., 2016).

The most important contribution of this study is determining the impact of technology consciousness. Technology is constantly changing, just like fashion. Consumers are sensitive to this change, as it is in fashion. This sensitiveness is called consciousness. Although there are studies on fashion consciousness in the literature (Lertwannawit \& Mandhachitara, 2012; Walsh et al., 2001; Shim \& Gehrt, 1996), there are not sufficient studies on technology consciousness. This study fills this gap in the literature from this point of view. As a result of the analysis it was found that technology consciousness has an effect on re-purchase Intention, but not on brand loyalty. In technological products, when an upper model of the product emerges, consumers tend to re-purchase this model. Brands can get the opportunity to increase their sales by adding new technological features to their products. This technological feature can be realized with small differences such as improvement of image quality, and development of different applications. It will not only increase the sales of brands but also make a difference to their competitors.

With the research done in the marketing literature, a consensus has been reached that brand loyalty provides a favorable return on the brand (Jones \& Taylor, 2007). The most important output of these positive returns is the re-purchase intention. The last finding of this study approves existing literature that brand loyalty will remain the main antecedent of re-purchase intention (Dick \& Basu, 1994). Brands that want to continue their sales should look for ways to create brand loyalty in their customers. In order to establish brand loyalty, factors affecting brand loyalty need to be known and should be studied. 
In addition to findings mentioned above, this study evaluates brand loyalty and re-purchase intention in smartphone marketing by adopting a different theoretical perspective. Although smartphone marketing is growing day to day, there is still scarce research in Turkey. This study sheds light on the smartphone market in Turkey and evaluates the results of the analysis in terms of marketing. In conclusion, this study contributes to better understanding of the antecedents of both brand loyalty and re-purchase intention in smartphone marketing.

\subsection{Limitations and Suggestions for Future Research}

This research reports important findings on brand loyalty and re-purchase intention in smartphone marketing, but several limitations exist.

Firstly, the sample in this study is suitable for the structure and the work of the study. Nevertheless, it should not be forgotten that this study has been applied to Turkish smartphone users. Different results can be obtained when a survey is applied to smartphone users in different cultures. For example, Walsh et al., (2001) examined brand consciousness by making cross-cultural comparisons and concluded that brand consciousness varies according to culture. In their study, Walsh et al. (2001) found that brand consciousness and other factors could vary in different cultures. To generalize the findings globally, comparative researchers involving other culture are essential. For this reason, the results of this study are limited to Turkish smartphone users.

Secondly, the term of technology consciousness, which derived from fashion consciousness, is one of the topics that have not been investigated. We adopted technology consciousness in smartphone marketing. To generalize the results in technological products, the technology consciousness factor should be examined on other technological products such as smart TV or tablet PC.

Thirdly, this study offers results and recommendations that will benefit brands. It is not to be expected that success will be achieved only by fulfilling these recommendations. Marketers should also take into account other important research done in this regard.

Fourthly, this research has been applied uni versity students who are highly educated persons. If this research had been applied to low-educated people, probably more differently results could be obtained. Future research can compare the differences between low educated individuals and highly educated individuals.

Lastly, when asked participants if the last two phone brands they used were the same. Respondent rate using the same brand was $38.1 \%$, whereas respondent rate using different brands was $61.5 \%$. This result showed that a large majority did not use the same phone brand. More results that are meaningful can be obtained if the majority of consumer groups that use the same brand is taken as the research sample. Surveys that would be conducted in the future, these two consumer groups (as long-term and short-term users) can be observed separately and the results can be compared.

\section{References}

Abdullah, F., Ward, R., \& Ahmed, E. (2016). Investigating the influence of the most commonly used external variables of TAM on students' Perceived Ease of Use (PEOU) and Perceived Usefulness (PU) of e-portfolios. Computers in Human Behavior, 63, 75-90. https://doi.org/10.1016/j.chb.2016.05.014

Ajzen, I. (1991). The theory of planned behavior. Organizational Behavior and Human Decision Processes, 50(2), 179-211. https://doi.org/10.1016/0749-5978(91)90020-T

Ashraf, A. R., Thongpapanl, N., \& Spyropoulou, S. (2016). The connection and disconnection between e-commerce businesses and their customers: Exploring the role of engagement, perceived usefulness, and perceived ease-of-use. Electronic Commerce Research and Applications, 20, 69-86. https://doi.org/10.1016/j.elerap.2016.10.001

Barnes, L., \& Lea-Greenwood, G. (2006). Fast fashioning the supply chain: Shaping the research agenda. Journal of Fashion Marketing and Management, 10(3), 259-271. https://doi.org/10.1108/13612020610679259

Bayraktar, E., Tatoglu, E., Turkyilmaz, A., Delen, D., \& Zaim, S. (2012). Measuring the efficiency of customer satisfaction and loyalty for mobile phone brands with DEA. Expert Systems with Applications, 39(1), 99-106. https://doi.org/10.1016/j.eswa.2011.06.041

Bharadwaj, S., Varadarajan, P. R., \& Fahy, J. (1993). Sustainable competitive advantage in service industries: a conceptual model and research propositions. Journal of Marketing, 57(10) 83-99. https://doi.org/10.2307/1252221

Bhattacharjee, A. (2001). Understanding information systems continuance: An expectation-confirmation model. 
MIS Quarterly, 25(3), 351-370. https://doi.org/10.2307/3250921

Chen, J. V., Yen, D. C., \& Chen, K. (2009). The acceptance and diffusion of the innovative smartphone use: A case study of a delivery service company in logistics. Information \& Management, 46(4), 241-248. https://doi.org/10.1016/j.im.2009.03.001

Chiu, C. M., \& Wang, E. T. G. (2008). Understanding Web-based learning continuance intention: The role of subjective task value. Information \& Management, 45(3), 194-201. https://doi.org/10.1016/j.im.2008.02.003

Chung, Y. S. (2015). Hedonic and utilitarian shopping values in airport shopping behavior. Journal of Air Transport Management, 49, 28-34. https://doi.org/10.1016/j.jairtraman.2015.07.003

Cyr, D., Head, M., \& Ivanov, A. (2006). Design aesthetics leading to m-loyalty in mobile commerce. Information \& Management, 43(8), 950-963. https://doi.org/10.1016/j.im.2006.08.009

Das, G. (2014). Linkages of retailer awareness, retailer association, and retailer perceived quality and retailer loyalty with purchase intention: A study of Indian food retail brands. Journal of Retailing and Consumer Services, 21(3), 284-292. https://doi.org/10.1016/j.jretconser.2014.02.005

Davis, F. D. (1989). Perceived usefulness, perceived ease of use, and user acceptance of information technology. MIS Quarterly, 13(3), 319-340. https://doi.org/10.2307/249008

DeLone, W., \& McLean, E. (2003).The DeLone and Mc Lean model of information systems success. Journal of Management Information Systems, 19(4), 9-30. https://doi.org/10.1080/07421222.2003.11045748

Dick, A. S., \& Basu, K. (1994). Customer Loyalty: Toward an integrated conceptual framework. Journal of the Academy of Marketing Science, 22(2), 99-113. https://link.springer.com/article/10.../0092070394222001

Elbedweihy, A. M., Jayawardhena, C., Elsharnouby, M. H., \& Elsharnouby, T. H. (2016). Customer relationship building: The role of brand attractiveness and consumer-brand identification. Journal of Business Research, 69(8), 2901-2910. https://doi.org/10.1016/j.jbusres.2015.12.059

Filieri, R., \& Lin, Z. (2016). The role of aesthetic, cultural, utilitarian and branding factors in young Chinese consumers' repurchase intention of smartphone brands. Computers in Human Behavior, 67, 139-150. https://doi.org/10.1016/j.chb.2016.09.057

Firat, A. F. in: Holman, \& Solomon R. M. (Eds.) (1991). The consumer in postmodernity, Advances in Consumer Research, Vol. 18, Association for Consumer Research, 70-76 Provo, UT.

Fishbein, M., \& Ajzen, I. (1975). Belief, attitude, intention, and Behavior: An introduction to the theory and research Addison-Wesley, Reading, MA.

Fornell, C., \& Larcker, D. F. (1981). Evaluating structural equation models with unobservable variables and measurement error. Journal of Marketing Research, 18(1), 39-51. https://doi.org/10.2307/3151312

Grayson, K., \& Shulman, D. (2000). Indexicality and the verification function of irreplaceable possessions: a semiotic analysis. Journal of Consumer Research, 27, 17-30. https://doi.org/10.1086/314306

Guan, J., \& Ma, N. (2003). Innovative capability and export performance of Chinese firms. Technovation, 23(9), 737-747. https://doi.org/10.1016/S0166-4972(02)00013-5

Hallowell, R., (1996). The relationships of customer satisfaction, customer loyalty, and profitability: an empirical study. International Journal of Service Industry Management, 7(4), 27-42. https://doi.org/10.1108/09564239610129931

Hamid, A. A., Razak, F. Z. A., Bakar, A. A., \& Abdullah, W. S. W. (2016). The Effects of Perceived Usefulness and Perceived Ease of Use on Continuance Intention to Use E-Government. Procedia Economics and Finance, 7th International Economics \& Business Management Conference (IEBMC 2015), 35, 644-649. https://doi.org/10.1016/S2212-5671(16)00079-4

Han, J., Seo, Y., \& Ko, E. (2016). Staging luxury experiences for understanding sustainable fashion consumption: A balance theory application. Journal of Business Research, In Press, Corrected Proof.

Han, S. H., Yun, M. H., Kim, K. J., \& Kwahk, J. (2000). Evaluation of product usability: development and validation of usability dimensions and design elements based on empirical models. International Journal of Industrial Ergonomics, 26, 477-488. https://doi.org/10.1016/S0169-8141(00)00019-6

Hennig-Thurau, T., Gwinner, K. P., \& Gremler, D. D. (2002). Understanding relationship marketing outcomes: an integration of relational benefits and relationship quality. Journal of Service Research, 5, 230-247. 
https://doi.org/10.1177/1094670502004003006

Hong, S. W., Han, S. H., \& Kim, K. J. (2008). Optimal balancing of multiple effective satisfaction dimensions: A case study on mobile phones. International Journal of Industrial Ergonomics, 38(3-4), 272-279. https://doi.org/10.1016/j.ergon.2007.09.002

Ince, H., Imamoğlu, S. Z., \& Türkcan, H. (2016). The Effect of Technological Innovation Capabilities and Absorptive Capacity on Firm Innovativeness: A Conceptual Framework. Procedia-Social and Behavioral Sciences, 235, 764-770. https://doi.org/10.1016/j.sbspro.2016.11.078

Jackson, C. M., Chow, S., \& Leitch, R. A. (1997). Toward an understanding of the behavioral intention to use an information system. Decision Sciences, 28(2), 357-389. https://doi.org/10.1111/j.1540-5915.1997.tb01315.x

Jeong, J., \& Jang, K. (2010). A study on the factors of smart-phone selection centered on actual users. e-Bus. Stud., 11(4), 361-379. https://doi.org/10.15719/geba.11.4.201011.361

Jones, T. O., \& Sasser, W. E. (1995). Why satisfied customers defect. Harvard Business Review, 6(73), 88-89.

Jones, T., \& Taylor, S. F. (2007). The conceptual domain of service loyalty: how many dimensions? Journal of Services Marketing, 21(1),36-51. https://doi.org/10.1108/08876040710726284

Kahn, B. E. (2016). Using Visual Design to Improve Customer Perceptions of Online Assortments. Journal of Retailing, 93(1), 29-42.https://doi.org/10.1016/j.jretai.2016.11.004

Katz, D. (1960). The functional approach to the study of attitudes. Public Opinion Quarterly, 24(2), 163-204. https://doi.org/10.1086/266945

Khan, U., Dhar, R., \& Wertenbroch, K. (2005). A behavioral decision theory perspective on hedonic and utilitarian choice. Chapter in Inside Consumption: Frontiers of Research on Consumer Motives, Goals, and Desires (Ed.), 1, 144-165.

Kim, D., Chun, H., \& Lee, H. (2014). Determining the factors that influence college students' adoption of smartphones. Journal of the Association for Information Science and Technology, 65(3), 578-588. https://doi.org/10.1002/asi.22987

Kim, M. K., Wong, S. F., Chang, Y., \& Park, J. H. (2016). Determinants of customer loyalty in the Korean smartphone market: Moderation effects of usage characteristics. Telematics and Informatics, 33, 936-946. https://doi.org/10.1016/j.tele.2016.02.006

Kim, M., Chang, Y., Park, M. C., \& Lee, J. (2015). The effects of service interactivity on the satisfaction and the loyalty of smartphone users. Telematics and Informatics, 32, 949-960. https://doi.org/10.1016/j.tele.2015.05.003

Kotler, P. (1984). Marketing Management: Analysis, Planning, and Control. (fifth ed.) Prentice-Hall, Englewood Cliffs, NJ.

Kressmann, F., Sirgy, M. J., Herrmann, A., Huber, F., Huber, S., \& Lee, D. J. (2006). Direct and indirect effects of self-image congruence on brand loyalty. Journal of Business Research, 59(9), 955-964. https://doi.org/10.1016/j.jbusres.2006.06.001

Lee, B. G., Yeo, Y. K., Kim, K. Y., \& Lee, J. H. (2010). Effects of trust and cognitive absorption on smart phone use and user satisfaction. The KIPS Transactions: PartD, 17(6), 471-480. https://doi.org/10.3745/KIPSTD.2010.17D.6.471

Lee, D., Moon, J., Kim, Y. J., \& Yi, M. Y. (2015). Antecedents and consequences of mobile phone usability: Linking simplicity and interactivity to satisfaction, trust, and brand loyalty. Information \& Management, 52, 295-304. https://doi.org/10.1016/j.im.2014.12.001

Lee, G. G., \& Lin, H. F. (2005). Customer perceptions of e-service quality in online shopping. International Journal of Retail \& Distribution Management, 33(2), 161-176. https://doi.org/10.1108/09590550510581485

Lee, H. J., Lim, H., Jolly, L.D., \& Lee, J. (2009). Consumer lifestyles and adoption of high-technology products: A case of South Korea. Journal of International Consumer Marketing, 21(2), 153-167. https://doi.org/10.1080/08961530802153854

Lertwannawit, A., \& Mandhachitara, R. (2012). Interpersonal effects on fashion consciousness and status consumption moderated by materialism in metropolitan men. Journal of Business Research, 65(10), 1408-1416. https://doi.org/10.1016/j.jbusres.2011.10.006

Lin, C. P., Tsai, Y. H., Chiu, C. K., \& Liu, C. P. (2015). Forecasting the purchase intention of IT product: Key 
roles of trust and environmental consciousness for IT firms. Technological Forecasting and Social Change, 99, 148-155. https://doi.org/10.1016/j.techfore.2015.06.034

Lin, M. Y. C., \& Ong, C. S. (2010). Understandıng Informatıon Systems Contınuance Intention: A Five-Factor Model of Personality Perspective, Pacific Asia Conference on Information Systems (PACIS), 366-376. https://pdfs.semanticscholar.org/.../2a1a846e2eb14d4d66a4

Liu, N., \& Yu, R. (2017). Identifying design feature factors critical to acceptance and usage behavior of smartphones. Computers in Human Behavior, 70, 131-142. https://doi.org/10.1016/j.chb.2016.12.073

Miller, N. B., Cowan, P. A., Cowan, C. P., \& Hetherington, E. M. (1993). Externalizing in preschoolers and early adolescents: A cross-study replication of a family model. Developmental Psychology, 29(1), 3-18. https://doi.org/10.1037/0012-1649.29.1.3

Milosavljevic, M. M., Navalpakkam, V., Koch, C., \& Rangel, A. (2012). Relative Visual Salience Differences Induce Sizable Bias in Consumer Choice, Journal of Consumer Psychology, 22(1), 67-74. https://doi.org/10.1016/j.jcps.2011.10.002

Mittal, V., Ross, W., \& Baldasaro, P. (1998). The asymmetric impact of negative and positive attribute-level performance on overall satisfaction and repurchase intentions. Journal of Marketing, 62(1), 33-47. https://doi.org/10.2307/1251801

Moore, S. G. (2015). Attitude Predictability and Helpfulness in Online Reviews: The Role of Explained Actions and Reactions. Journal of Consumer Research, 42, 30-44. https://doi.org/10.1093/jcr/ucv003

Oliver, R. L. (1980). A Cognitive Model for the Antecedents and Consequences of Satisfaction. Journal of Marketing Research, 17, 460-469. https://doi.org/10.2307/3150499

Oliver, R. L., \& DeSarbo, W. S. (1988). Response determinants in satisfaction judgments. Journal of Consumer Research, 14, 495-508. https://doi.org/10.1086/209131

Ozturk, A. B., Bilgihan, A., Nusair, K., \& Okumus, F. (2016). What keeps the mobile hotel booking users loyal? Investigating the roles of self-efficacy, compatibility, perceived ease of use, and perceived convenience. International Journal of Information Management, 36(6), 1350-1359. https://doi.org/10.1016/j.ijinfomgt.2016.04.005

Ozturk, A. B., Nusair, K., Okumus, F., \& Hua, N. (2016). The role of utilitarian and hedonic values on users' continued usage intention in a mobile hotel-booking environment. International Journal of Hospitality Management, 57,106-115. https://doi.org/10.1016/j.ijhm.2016.06.007

Parasuraman, A. (1997). Reflections on Gaining Competitive Advantage through Customer Value. Journal of the Academy of Marketing Science, 25(2), 154-161. https://doi.org/10.1007/BF02894351

Pedeliento, G., Andreini, D., Bergamaschi, M., \& Salo, J. (2016). Brand and product attachment in an industrial context: The effects on brand loyalty. Industrial Marketing Management, 53, 194-206. https://doi.org/10.1016/j.indmarman.2015.06.007

Persaud, A., \& Azhar, I. (2012). Inno vative mobile marketing via smartphones: Are consumers ready? Marketing Intelligence \& Planning, 30 (4), 418-443. https://doi.org/10.1108/02634501211231883

Pew Research Center. (2016).

http://www.pe wglobal.org/2016/02/22/smartphone-ownership-and-internet-usage-continues-to-climb-in-em erging-economies/

Pitt, L. F., Parent, M., Junglas, I., Chan, A., \& Spyropoulou, S. (2011). Integrating the smartphone into a sound environmental information systems strategy: Principles, practices and a research agenda. The Journal of Strategic Information Systems, 20(1), 27-37. https://doi.org/10.1016/j.jsis.2010.09.005

Rahim, A., Safin, S. Z., Kheng, L. K., Abbas, N., \& Ali, S. M. (2016). Factors Influencing Purchasing Intention of Smartphone among University Students, Procedia Economics and Finance. The Fifth International Conference on Marketing and Retailing (5th INCOMaR), 37, 245-253.

Reuver, M., Nikou, S., \& Bouwman, H. (2015). The interplay of costs, trust and loyalty in a service industry in transition: The moderating effect of smartphone adoption. Telematics and Informatics, 32(4), 694-700. https://doi.org/10.1016/j.tele.2015.02.008

Russell-Bennett, R., Härtel, C. E. J., \& Worthington, S. (2013). Exploring a functional approach to attitudinal brand loyalty. Australasian Marketing Journal (AMJ), 21(1), 43-51. 
https://doi.org/10.1016/j.ausmj.2012.08.001

Schifferstein, H. N. J., \& Zwartkruis-Pilgrim, E. P. H. (2008). Consumer-product attachment: Measurement and design implications. International Journal of Design, 2(3), 1-13

Shim, S., \& Gehrt, K. C. (1996). Hispanic and Native American adolescents: An exploratory study of their approach to shopping. Journal of Retailing, 72(3), 307-324. https://doi.org/10.1016/S0022-4359(96)90032-9

Shin, D. (2009). Determinants of customer acceptance of multi-service network. Information and Management, 46(1), 16-22. https://doi.org/10.1016/j.im.2008.05.004

Shin, D. H. (2015). Effect of the customer experience on satisfaction with smartphones: Assessing smart satisfaction index with partial least squares. Telecommunications Policy, 39, 627-641. https://doi.org/10.1016/j.telpol.2014.10.001

Suki, N. (2012). Correlations of perceived flow, perceived system quality, perceived information quality, and perceived user trust on mobile social networking service users' loyalty. Journal of Information Technology Research,5(2), 1-14. https://doi.org/10.4018/jitr.2012040101

Tho, N. X., Lai, M. T., \& Yan, H. (2017). The Effect of Perceived Risk on Repurchase Intention and Word - of Mouth in the Mobile Telecommunication Market: A Case Study from Vietnam. International Business Research, 10(3), 8-19. https://doi.org/10.5539/ibr.v10n3p8

Walsh, G., Mitchell, V. W., \& Hennig-Thurau, T. (2001). German consumer decision-making styles. Journal of Consumer Affairs, 35(1), 73-95. https://doi.org/10.1111/j.1745-6606.2001.tb00103.x

Wang, C., Lee, M. K. O., \& Hua, Z. (2015). A Theory of social media dependence: Evidence from mic roblog users. Decision Support Systems, 69, 40-49. https://doi.org/10.1016/j.dss.2014.11.002

Webster, F.E. (1992). The changing role of marketing in the Corporation. Journal of Marketing, 56(4), 1-17. https://doi.org/10.2307/1251983

Yang, Z., \& Petersson, R. T. (2004). Customer perceived value, satisfaction, and loyalty: the role of switching costs. Psychology and Marketing, 21(10) 799-822. https://doi.org/10.1002/mar.20030

Yeh, C. H., Wang, Y. S., \& Yieh, K. (2016). Predicting smartphone brand loyalty: Consumer value and consumer-brand identification perspectives. International Journal of Information Management, 36(3), 245-257. https://doi.org/10.1016/j.ijinfomgt.2015.11.013

Young, K. S. (1999). Internet addiction: symptoms, evaluation and treatment. Innovations in clinical practice: A source book, 19-31, Professional Resouce Press, Sarasota, FL, 17, 19-31.

Yun, M. H., Han, S. H., Hong, S. W., \& Kim, J. (2003). Incorporating user satisfaction into the look-and-feel of mobile phone design. Ergonomics, 46(13-14), 1423-1440. https://doi.org/10.1080/00140130310001610919

Zeithaml, V. A. (1988). Consumer perceptions of price, quality, and value: a means-end model and synthesis of evidence. Journal of Marketing, 52(3), 2-22. https://doi.org/10.2307/1251446

\section{Copyrights}

Copyright for this article is retained by the author(s), with first publication rights granted to the journal.

This is an open-access article distributed under the terms and conditions of the Creative Commons Attribution license (http://creativecommons.org/licenses/by/4.0/). 